Article

\title{
Deparmental Auction State Officers' Public Service Of Makassar City
}

\author{
Lukman Hakim 1 \\ 1 Lecturer of State Administration Science, University of Muhammadiyah Makassar. \\ Jl. Sultan Alauddin 259, Makssar, South Sulawesi, 90221. Indonesi; lukman.hakim@unismuh.ac.id.
}

\begin{abstract}
This research was focused on Public Service of departmental auction state officers of Makassar . It aimed to determine the state officers' performance who passed departmental auction that had been assessed based on competence, and integrity in particular, the ability to provide and develop good service to the community at the 9 Local Government Work Unit (SKPD) Makassar, namely the Regional Revenue Board of Makassar City, the Land Board of Makassar City, the Office of Investment and Integrated One Stop Service of Makassar City and the Department of Population and Civil Registration of Makassar City, Ujung Pandang District Office, Makassar District, Rappocini District, Bontoala District , and Panakkukang District . The 9 SKPD were chosen purposively from 53 SKPD within the Makassar City Administration by considering the representation of SKPD of the Agency and the Department as well as the representation of the district Institution located in the northern, middle and southern part of Makassar City. Interviews and observation data were collected by 3 interviewers and narrated as facts and elaborated by the research team with qualitative and normative studies. The result of the research shown that the state officers' performance in Makassar city administration area had been able to develop good service to the society at 9 Local Government Work Unit (SKPD) of Makassar City. However, it was necessary to improve the quality of human relations especially for the leading position of all SKPD so that the communication can be better served to the citizens. System reward dan punishment need to be upgraded and enforced as a trigger of employees' motivation in work.
\end{abstract}

Keywords: Service, officers, departmental auction

\section{Introduction}

One of the objectives of the position promotional of office through departmental auctions in the government of Makassar City is to have officers who are able to provide public services in their respective work units either in institutions, agencies or at the district level. Officers of state civil officer who passed the auction selection recruitment are professional structural officers, highly competent, perform well, integrity, as per the organization's expectations. "In other words, through the auction, will get the best structural officers in accordance with Law No. 5 of 2014 on the State Civil Officer (ASN) and Law Number 25 Year 2009 on public services that emphasize the importance of improvements in the quality of public services including improving transparency, efficiency and creating good governance.

The Makassar City Government auctioned positions for the district head, sub-district heads and other heads of work units as one of the strategic steps to answer the aspirations of the people who are not satisfied with the performance of a number of district head and sub-district heads and other SKPD leaders who carry out the services to various affairs of the visitors. Bureaucracy should be able to perform services that are more oriented to the features of modern organizations that provide services quickly, accurately, accurately, openly while maintaining quality, cost efficiency and timeliness (Anonymous, 2017). Therefore, the loyalty of the officer performing the service every day becomes the study in this research. So the performance of government officers need to be improved and upgraded. The main problem that will be answered in this research is the low performance of public service of local government officer of Makassar City which resulted the decreasing of performance of local government 
especially at local government work unit level (SKPD) either at institute / service level, and at district and district level.

\section{Methodology}

This research was conducted at 9 working units of local government (SKPD) of Makassar. namely the Regional Revenue Board of Makassar City, the Land Board of Makassar City, the Office of Investment and Integrated One Stop Service of Makassar City and the Department of Population and Civil Registration of Makassar City, Ujung Pandang District Office, Makassar District, Rappocini District , Bontoala District, and Panakkukang District . 9 SKPD agencies were selected purposively from 53 SKPD within the Makassar City Administration by considering the representation of SKPD of the Agency and the Department as well as the representation of the District institutions located in the northern, middle and southern parts of Makassar City. Interview and observation data were collected by 3 interviewers and narrated in the form of facts and elaborated by the research team with qualitative studies. The qualitative approach provided an overview (description), understanding (insight), comprehensive (hollistic), and complete (exhaustive) to the issues discussed. The data obtained in this study consisted of primary data and secondary data. Primary data collection was done through observation and in-depth interviews (depht interview) against the target object of research were the officer / local government officers of Makassar City starting from service SKPD level of service until SKPD district.

Flow Chart of Research
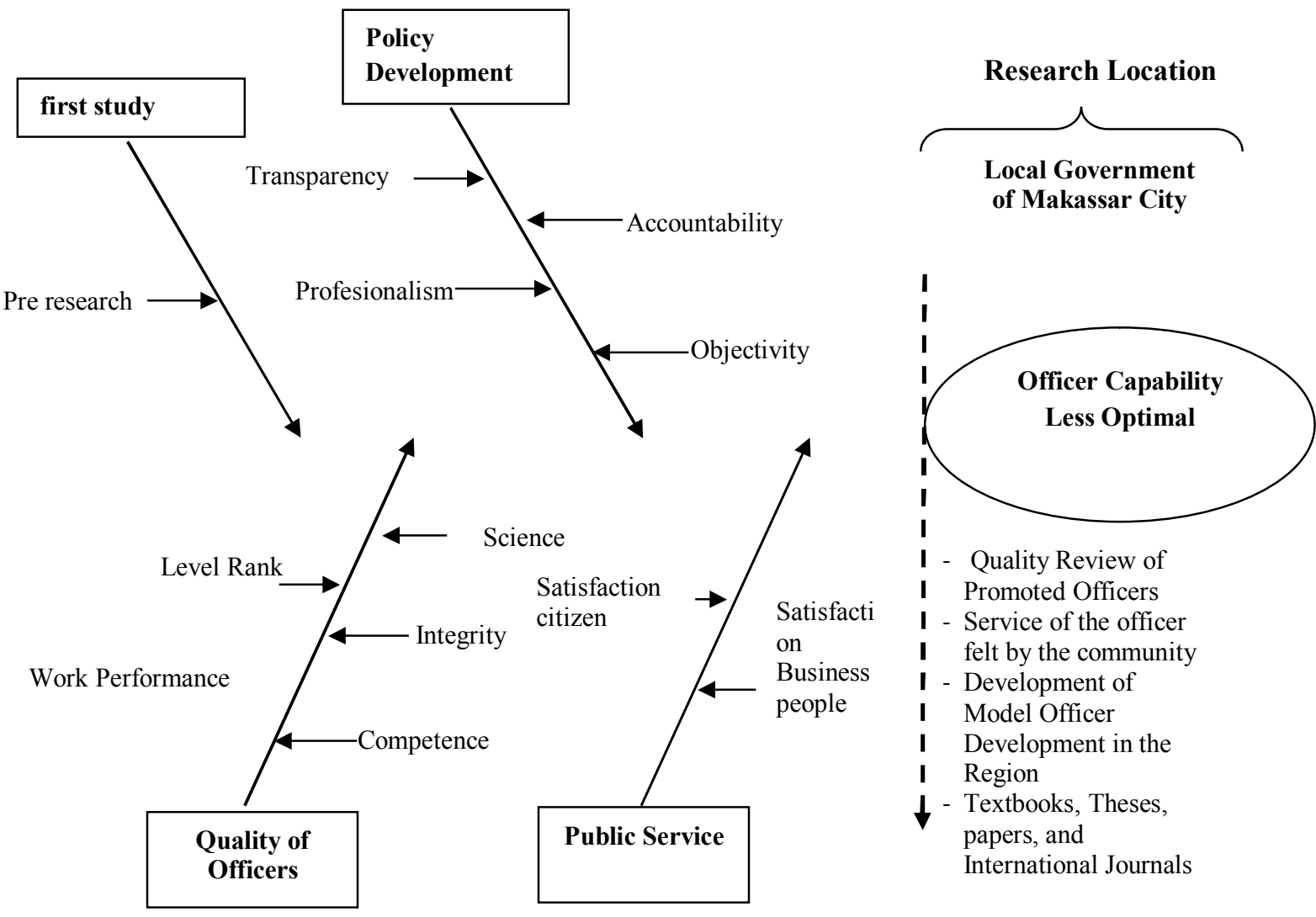

Output Target (Effect)

Figure 1. Public Service of State Officer Departmental Auction Result of Makassar City .

\section{Results And Discussion}

3.1. Duties and Responsibilities of State Officers (ASN) of Makassar City Government.

One of the duties of the State officers (ASN) based on Law Number 5 Year 2014 is having 
commitment, moral integrity and responsibility to public service (Article 3 ) and providing services to the public in an honest, responsive, prompt, accurate, efficient, effective and courteous (Article 4). This is the basis for the selection of auction selection team of Mayor of Makassar to place qualified and competent qualifications and integrity to be promoted in the mandated position. For 3 years since the auction policy began in 2014 and began to place officers at all echelons of the Makassar City government, the officers who have served are evaluated on an ongoing basis regarding the performance and achievements made on the Job and Work Unit respectively. The promotion cycle of the official results of the ongoing auction of office is marked by the change of officers in various SKPD including at the Agency, Department and District levels. Therefore the performance of officers can also be assessed on the extent to which able to provide services to the community unity of each work. The State Civil Service Officer must be able to position himself as a public servant or public servant, and may facilitate public affairs, prioritizing public interests rather than personal or group interests. However, in reality there are not many civil state officer capable of understanding it, so it is not surprising that officer behavior does not give priority to public interest so that public expectation to get good and satisfactory service has not been fully fulfilled (Minfiattin, Hartutiningsih, Achmad Djumlani, 2017).

\subsection{Service of Officers and Agency in Makassar City Government}

Regional Revenue Board of Makassar City, Land Board of Makassar City, Department of Population and Civil Registry and Investment Service Office and Integrated One Stop Service is element of local government organizer report to Mayor of Makassar. This agency has been headed by a civil state officer official of the auction results. One of the performance needs to be assessed is the ability to provide public services in the agency where the duty.

Community service in the Regional Revenue Board is crowded and high demanding. According to the Secretary of the Agency as an informant stated that the number of taxpayers who come every day to take care of their taxes, there is a mandatory tax, restaurant taxes, and so forth. Each day can serve dozens of people who come, without limiting the target that needs service according to their needs. In the last 1 month the number of people who come to be served continues to increase and it can be considered in the service. All taxation arrangements are centered on the 1st floor in a service room called integrated tax services. The left and right wing sections of the room are entered in writing service open from $7.30 \mathrm{am}$ and close at $4 \mathrm{pm}$. But in the data input section on the $3 \mathrm{rd}$ and 2nd floor, home hours are not specified because sometimes over night only to finish the data related to taxation. This is a technical issue of taxation that sometimes takes more time.

Viewed from the side of supervision, every room available CCTV monitoring tool to control the room and monitor the condition of employees of each room, especially those who take care of the technical taxation. There is also the name Tim Passukki who deal with the problem of advertisements, advertisements in pairs on the shoulders of the road that if not in accordance with the rules then everything will be disciplined by the supervision team. So the average employee at the office hours during the day, they are outside in the field to record and supervise, except the technical part of taxation that remain alert in the office, and others a lot of activity outside the office and meet again in the afternoon to fill the attendance.

The services provided are always strived in order to avoid any delay, what else is now onlinebased services that make it easier for visitors in making tax payments. This will affect the quality of services provided and therefore leaders in this SKPD always emphasize to the officers, to always be careful in serving the citizens and pay attention to detail their needs. Efforts are made to avoid any complaints from citizens in the service problems, including friendly attitude in serving and always be polite supported by a neat clothes. It will be a separate image of the community when providing services with poor performance. For work facilities in this agency is enough available, work desk, computer all is quite complete in order to optimize the available work tools to support the maximum service.

The Office of Revenue Board of Makassar City has a new organizational structure that was previously the Regional Revenue Service. With the change into Regional Revenue Board, this body 
has a function as revenue coordinator in the original income of Makssar City. The main function of Bapenda is as PAD coordinator as well as functioning to provide services related to local taxes and user charges that manage approximately 11 local taxes and 2 local levies, such as land tax and building (PBB), restaurant tax, tax on land and building (BPHTB), Parking Tax and others. To provide easy service to the community prepared the room "Integrated Tax Service" to facilitate the public to make tax payments, using an integrated system. For people who will make any tax payments, can come use the room. The target of tax revenue in APBD is targeted at 1.145 trillion. This is more to the target amount of tax paid by the taxpayer. There is a 1 billion more increase over the previous year and each type of tax has its own target. Achievement of tax realization in 2017 has reached 1 trillion more than the realization of the target that is given. In Bapenda itself there are 4 areas namely 2 technical fields that serve technically taxation, and 2 fields that go to the field of data and field of surveillance. The field of data collection goes to the field of data collection to taxpayers or tax objects that have not been registered, and there are areas that routinely conduct supervision related to tax objects that may violate the rules. The field of supervision is in charge of ordering, such as billboards that do not pay taxes, and advertisements that are installed does not fit the place. The issue of taxpayer handling is all free of charge, and this is a direct instruction from the Makassar City government that all free-of-charge management is available in the Standard Operating Procedures (SOP) that all forms of free service are free cost. SOP types are available quite a lot because of the many tax affairs that are handled and all have their respective SOPs. Implementation of SOPs has been well executed, and the communities served are never protested by the rules applied because they have clear regulations and do not burden the public.

Department that provides the best service of course can not be separated from the obtained award. In the Regional Revenue Board of Makassar has been awarded standardization of ISO certified services in other words have international standards such as awards in the receipt of Land Tax Building (PBB) and the Cost of Land and Building Rights (BPHTB). Actually without reward does not mean nothing since it is only a symbol. So without it these agencies always provide the best service without having to pursue this type of award.

Organizational culture based on the values of sincerity is always socialized to employees, because with sincere work will be very valuable worship, and the obligation of every human being to work energetically in providing the best service to the community without ever complaining. With these values will create a quality public service, and an appreciation as an innovative employee will be obtained from anyone if the morale continues to be maintained based on sincerity values. Similarly, the attitude of serving such as politeness, hospitality and adequate room is always applied to all employees who provide direct services to the community.

Serving people with a superior service culture requires constant improvement of the personal quality of employees. The quality of individual employees should be improved from the soft skills side continuously and regularly at all times. Building a sincere and wholehearted human resource to provide service is not easy and simple. In life there are good people and negative people and both are always eternal coexisting throughout the ages, as dark and light are always eternal coexistence. Likewise the good and the negative are always eternal coexist in the workplace. Therefore, in building a strong service culture, leaders must always be aware that even negative forces will always be present to hinder the growth of a strong culture. Awareness to examine and evaluate the day-to-day situation of organizational culture is important so that the risks of non-supportive forces can be minimized. In contrast to services at the City Land Agency of Makassar, employees of the state that serves the community in the affairs of land certificates provide certificate services in sufficient quantities. The results of interviews with administrative heads explain that the average number of visitors who come every day in this agency as many as 300 people per day. In this office there is no target number of visitors and the service personnel do not limit the number of targets to be served. The number of visitors in the last 1 month is increasing. The types of affairs that are mostly related to the needs of the community are the management of land certificates, checking of land certificates, and requests for certification of land certificates. Community affairs can be completed for 1 day. Service is often delayed due to incomplete file, the application is not 
proportional to the number of employees. The attitude of the servants in providing services to the community, looks friendly and well-dressed, polite and gentle. In the waiting room the air service is quite cold, as well as having office facilities such as computers, chairs, tables, and air conditioner. Service officers also often communicate with visitors who come because there is a security guard who on duty every day. Work in this office is supported by the SOP which since 2010 has been applied. The number of SOPs in this office is 30 SOPs. The average presence of officers in the office is quite good starting at $07.30-17.00$. As an office that receives the cost of processing land certificates, then in this office there is a payment obligation that is State Cash Payment (PNBP). That is one of the leading aspects so that the Office of Land Agency of Makassar City has ever received an award charter as role model. The organizer of the "Good" public service on January 24 , 2018, granted by the Ministry of Administrative Reform and Bureaucratic Reform by the Deputy for Public Service. However, in this Office no employee performs as a good servant. Nevertheless, the results of interviews with community users of the service behind the name and the application of the certificate declared its affairs completed about 20 days to 6 months. One cause of work is often delayed because of the large number of letters that accumulate. Despite the timely and friendly presence of employees, there is a slightly disappointing officer with a lack of communication with the community.

The phenomenon of officer services in the Office of Population and Civil Records of Makassar City is almost the same situation and service conditions at the Office of Finance Agency of Makassar City and the Office of Land Agency of Makassar City. It is just the number of visitors served relatively more that the average between 300 to 500 people per day by using a modern queue number system. The number of visitors last month continues to increase, due to the proximity of elections related to the issue of ID cards and Family Card. The delay in community service is caused by the incomplete file and the lack of understanding of the file requirements. For example, first take a letter at the head of the village office, then to the district office and finally in the civil registry office. There are also visitors who should have their files at the head of the district but they come to the Population and Civil Registry Office. Thus the information on the service line still needs to be communicated to the public to give more efficient service satisfaction.

Services that are often delayed also occur in the Office of Investment and Integrated Services One Roof Makassar, especially in the arrangement of permits SITU, SIUP and TDU. The permit is usually completed on the same day, however the required file is often incomplete and consequently if the file is already running, the outgoing permit takes 5 to 7 business days. This is why services are often delayed because of incomplete requirements.

\subsection{Service of District Officers in Makassar City Government}

Officers of the results of the auction office at the district office in Makassar City has performed the task and is expected to provide the best performance in service to the community. One of the criteria in the selection of job auction is the fulfillment of competence and integrity of officers in carrying out the task. The district head as the head of government in the districts is in charge of assisting the Mayor in governance at the district level. The attitude of personality that every head needs to be guarded is the feeling of power when giving service to society. The power of the district head often monopolizes community service, while the public expects its affairs to be quickly resolved with clear legal certainty. The services provided by the government are always expected to facilitate and benefit the community. Therefore, the satisfaction of the people in the settlement of various kinds of affairs can only be obtained through the government that carry out the service well and give assurance that the community affairs can be completed on time.

The public services provided by the city government through the district administration are very different from the services provided by a company in the business. In the business world, there is competition and intense competition, so anyone who is able to provide a service that facilitates and benefits the customer, will be the winner in the business. While in the preferred government is public service which is oriented to the public interest (community) without prioritizing the financial benefits that result in the higher burden of community life. 
Ujung Pandang District Office always strive to provide the best service, based on ethics that must be maintained in providing services to the community, such as $3 S$ (smile, greetings, and greetings). Service is supported by Standard Operating Procedures (SOP) available which is similar to other district offices in Makassar. The number of service SOPs is quite adequate ie 20 SOPs and their implementation begins since 2014. These SOPs provide good benefits in the service to the community and will be further improved again in the next year. Implementation of the SOP is inseparable from the complaints of pro and contra citizens. But overall all can still be resolved and run as expected. Therefore every week the head of district evaluates the work and even every day coordinates with the related service sections to be able to follow up if there are errors, supported by the availability of an integrated service counter. With service according to SOP proves with decreasing of public complaint and always try to give explanation if there is something inhibiting. For example the management of Building Permit (IMB) which is often complained of its service, then with SOP and the principle of satisfying the customer then all related to the making of the recommendation can be accelerated the settlement and so submitted to the Office of Population and Civil Registration to be resolved. It's just that the settlement process depends on the performance of the Office of Population and Civil Registry. Ujung Pandang District Office has been awarded as proven by ISO certificate obtained from Makassar city government.

Similarly, service at the Rappocini District Office, visitors who come every day can be seen in the service room. Visitors who come will be monitored automatically through the queue machine, and the amount fluctuates until the office service is closed. The increase in visitors last month increased steadily, but the increase is not too high because the previous service is quite a lot. The most cultivated citizen needs are ID Card and Family Card by $3 \times 24$ hours as time adjusted to the existing SOP. SOPs have been implemented since 2015, and the implementation constraints are rare, even the visitors feel more helped by the SOPs plus the service innovations that they provide. Every servant in this office is always encouraged to provide the best service to the community, such as being friendly, polite and gentle to the community because this institution has the slogan: Sombere means Polite, Objective, Easy, Clean, Efficient, Friendly and Effective.

Service at the Rappocini District Office is supported by the availability of a comfortable waiting room, regular chairs and rooms equipped with air-conditioning and CCTV. CCTV is provided to support employee performance in order to avoid of disobedience rules and make it easier to be monitored. In the service room is provided Mini War Room to monitor all kinds of activities officers with the community. This is one of the innovation services provided. For services such as KK and KTP which is the most demanded by the visitors, the subdistrict officer provides the motor of hall service. This is useful for bringing people to the halls if they take care such as KK, KTP and others without needing to come alone. Office facilities such as desks, computers are available, including attention to troubled office facilities so they can be acted upon and handled quickly. If it is permitted in this situation: slow and less service, so it can be a problem in service. Things like this are expected from a public official who has integrity and good performance.

Excellent service is also indicated by the need for direct interaction with citizens to better understand what their needs. Officers who are in the service strived to be more interactive to the citizens. That is one of the successes in the ministry so that the Mayor of Makassar awarded as the best service provider under the category of Public Service Provider Units for 2 years in a row from 2016 to 2017, and the award is stored in the service room.

Service at Bontoala District Office averages were 50 people daily. Service is always done quickly because it is supported by many officers who are ready to serve the needs of citizens. Last month of this service is quite increased because in this office also serves the recording of electronic ID card. There are still some visitors who have not done the Electronic ID card recording so many who come because the elections will be held Governor of South Sulawesi and elections Mayor of Makassar. As for the needs of visitors in the District Bontoala, among others, the recording of ID cards, the arrangement of Family Card, payment of motor taxes and cars (special counter by giving 5 percent dispensation), the business license, the management of IMB, the handling of inheritance, 
and the arrangement of the introduction letter of marriage certificate with the service a day (one day service). The average community here can complete its affairs within the same day. Service is often delayed if the required file is required by the Camat signature, while the head is again meeting or is away. The principle of friendly service of the officer and the priority of excellent service and the cold waiting room becomes the main thing in the service at Bontoala District office. Service standards based on SOP have been applied since 2010 with 20 types of SOPs. That is why Bontoala District Office has received 3 awards, both from Fajar print media and from Mayor of Makassar as district office with the best service.

The service in Makassar District Office is shown by the average number of visitors 40 people per day. In this office there is no target number of visitors and the service personnel do not limit the target. The number of visitors in the last 1 month increased especially let alone elections. The type of affairs that most associated with the purposes of society in this office is the management of ID cards and Family Card that can be completed about 5 minutes. Service is often delayed due to offline network or off lights. The attitude of the servants in providing services to the public looks friendly and well-dressed. The availability of waiting room for service is quite cold, and has office facilities such as computer, chairs, tables, and ac. Service personnel also often communicate with visitors who come. This office has 14 SOPs and has been implemented since 2014. The average presence of officers in this office around 07.30-15.30. And there is no obligation of payment or free of charge in the service. Makassar District Office was awarded an award from the Mayor of Makassar as the best community service with a champion of hope, although personally no employee has ever received an award.

Panakkukang District Office has employees and employees who use rolling system. Each week service staff are taken from each village in the District Panakkukang rollingly. The average number of visitors who come every day in this agency as many as 50 people per day according to the data stated at guest book last 2 months. In this office there is also no target number of visitors and the service personnel do not limit the target. According to him, the number of visitors in the last 1 month is increasing. The type of affairs that most related to the needs of the community is the maintenance of ID cards, and Family Card (KK). Public affairs can be completed in this office depending on the presence of leaders in the office, and strived within 5 minutes is completed. The attitude of the servants in providing services seemed friendly and well-dressed. The waiting room for service is quite cold, and has office facilities such as computer, chairs, tables, and ac. Service personnel also often communicate with visitors who come. This office has 20 SOPs and applied since 2011. The average presence of officers in this office, at around 07.30-15.30. and no payment obligations or free. This office was awarded the award for best community service 3 , given by the Mayor of Makassar. However, in this Office no employee performs as a good servant. Public service is one of the important tasks that can not be ignored by the local government because if the service component stagnated then almost certainly all sectors will impact congestion. Therefore there needs to be good planning and even need to be formulated standard of service to society in accordance with authority given by central government to local government. In the Law No. 5 of 2014 on State Civil Officer in article 1 it is mentioned that the State Civil Officer hereinafter abbreviated as ASN is a profession for employees and government employees with work agreements working in government agencies. In performing its duties, the State Civil Officer must be professional and integrity (Sunda, Cliff M. and Johny Lumolos and Sarah Sambiran, 2017). Based on this, the State Civil Officer has always been required to have full loyalty and obedience in carrying out its duties that focus attention and mind and mobilize all power and energy in a useful and effective manner. The State Civil Officer is able to position itself as a public servant or public servant, and may facilitate public affairs, prioritizing public interests rather than personal or group interests. However, in reality there are not many civil state officer capable of understanding it, so it is not surprising that officer behavior does not give priority to public interest so that people's expectation to get good and satisfactory service has not been fully fulfilled (Minfiattin and Hartutiningsih and Achmad Djumlani, 2017)

Performance of the State Officer is required for professionals in providing services to the public. More and more public services are needed, in line with the demands of the public that require 
prompt, timely service and in the process of convenient, friendly, fast and cheap and fair service. Public service is the spearhead of governance in relating to society. Thus the success of public services is the success of the government, but the facts in Makassar City almost all agencies still have weaknesses in service to the community. In other words, officers who have been promoted to positions in general auctions have worked professionally and with integrity, although they still need to improve the system, procedures and quality of human resources and technology in optimizing services.

\section{Model Development}

Efforts to improve public services in government agencies in SKPD structures, offices and district s can not be separated from the instrument of Law Number 25 of 2009 which states that the state is obliged to serve every citizen and citizen to fulfill their basic rights and needs within the framework of public services. Public service is an activity that must be done in line with the expectations and demands of all citizens and visitors about the improvement of public services. Therefore, in Law Number 5 Year 2014, it is necessary to build civil state officer that has integrity, professional, neutral and free from political intervention, clean from corruption, collusion and nepotism practice and able to provide public service for the society. Based on this matter, in this study need to review and describe a model of public service framework supported quality civil state officer, where the officer in question is an official who has followed the auction office in Makassar. Some of the input items as a factor supporting the improvement of the quality of the officer are human relations, communication climate, time consistency, service target, reward and punishment, and financial supporting. A public service officer should have a good human relation to the client being served. The form of human relations is the creation of a cold and comfortable communication climate between servants and customers (clients), so psychologically improve the confidence for the client that all the necessary business can be solved smoothly. Impaired client perceptions can arise from inconsistent appointments and unfulfilled times. Therefore, service targets such as timeliness with the number of people served becomes important for the consistency of service schedules can be more effective. Regardless of any regulation of service with adequate quality of human resources support, then the factor of financing support (financial supporting) become the determinant of service effectiveness. Without adequate financing, human resources and technology will be difficult to develop. Welfare associated with basic human needs requires rewards for both salary, health benefits and housing allowances. The availability of shelter will spur the increase of motivation / morale of employees, However, in addition to the given rewards, it is also necessary to punishment (sanctions). Those who achieve will be given adequate reward. Motivation and knowlege will be given to those who not achieve yet.

Output from the framework of this research is the achievement of the outcome of the concept of excellent service that is accountable and transparent. While its outcomes is utilization of the outcome in improving the employees' performance SKPD Makassar city government. The SKPD Service Model is described in the scheme as follows: 


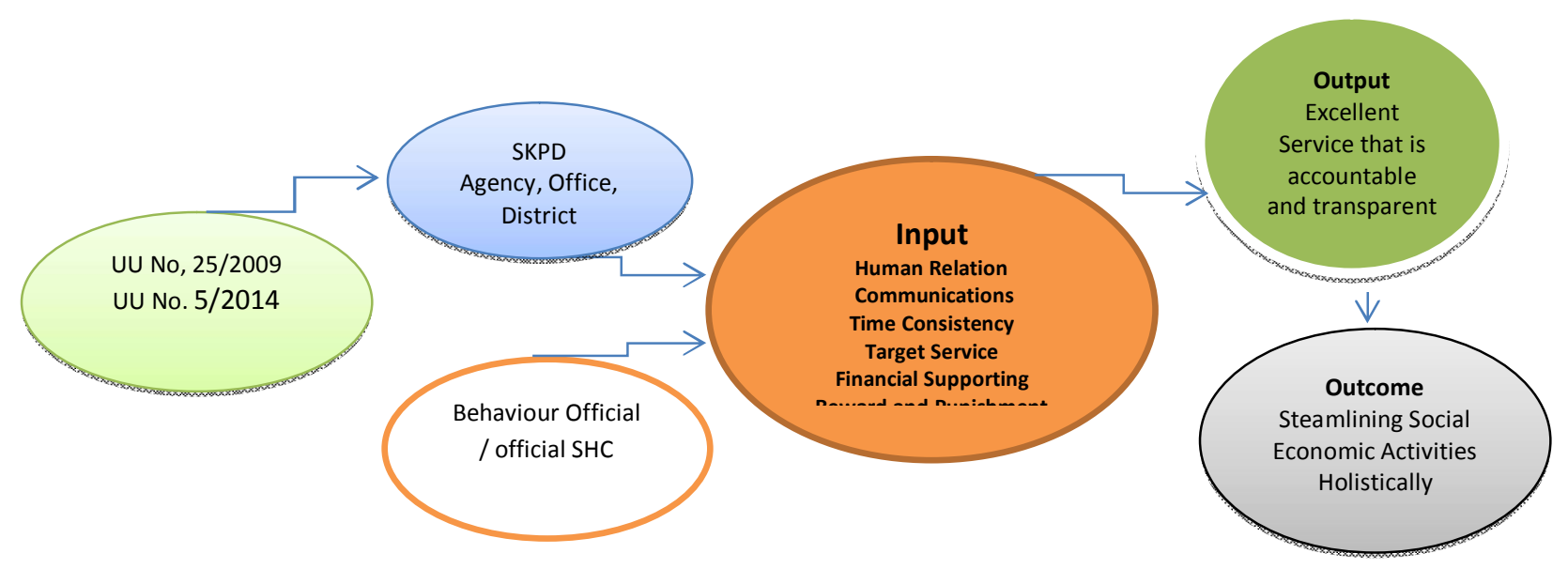

\section{Conclusions and recommendations \\ Conclusion}

1. State officers' performance of the state of the departmental auction results within the administrative area of Makassar City had been able to develop good service to the community at 9 Local Government Work Unit (SKPD) Makassar.

2. The competence, professionalism and integrity of officers have been applied in providing services, although the busyness of officers, heads of agencies, offices and district heads is still one of the factors causing slow service under targeted time.

3. Working facilities are adequate with the availability of work desks, computers and other working equipment in order to optimize the available work tools to support maximum service.

4. Some Local Government Work Units (SKPD), both agencies, departments and district offices have developed standard operating procedure (SOP) in providing services and free of charge.

5. ISO award a achievement in service has been obtained several SKPD by the Mayor of Makassar.

\section{Suggestion}

1. Need to improve the quality of human relation (HR) officers of the results of the auction particularly the front-runner on all SKPD so that the communication to the citizens is served better and intensive, eliminate the exclusiveness climate in work.

2. The intensity of official meetings in SKPD structure, offices or district $s$ as far as possible does not reduce the acceleration of services needed by citizens.

3. The reward and punishment system needs to be enforced as a motivator for employees' motivation in work.

4. The financing of an excellent and integrated service system needs to be increased both the cost of improving the welfare of lumpsum, transportation, meals, and applied technology.

5. Punishent in the assessment of service performance is necessary and should be enforced as one of the instruments of enforcement of the State Civil Officer Act No. 5 of 2014.

\section{References}

Anonim, 2017. Penerapan Diplomasi Kota Makassar, https://monicaro maulywe u.wordpress.com/2017/07/16/penerapan-e-government-serta-paradiplomasi-kota-makassar

Hasibuan, Z. A. (April 2007). Langkah-Langkah Strategis dan Taktis Pengembangan e-Government Untuk Pemda. Jurnal Informasi I UI Vol 3 No 1, 66-70.

Maisaroh, Siti dkk. 2014. Lelang Jabatan Kepala Sekolah dan Kualitas Layanan Pendidikan, Jurnal Administrasi Publik Fakultas IImu Administrasi Universitas Brawijaya Malang Vol 3 Nomor 11 Halaman 1917-1923

Minfiattin dan Hartutiningsih dan Achmad Djumlani, 2017. Kinerja Aparatur Sipil Negara (Asn) dalam 
Pelayanan Publik Di Kantor District Loa Janan, e-Journal Administrative Reform Fisip Universitas Mulawarman, http://ar.mian.fisip-unmul.ac.id/site/?p=1200

Prabowo, Bastian dkk. 2016. Pengaruh Promosi Jabatan Terhadap Motivasi Kerja dan Prestasi Kerja" Jurnal Administrasi Bisnis, Fakultas Ilmu Administrasi Universitas Brawijaya Malang, Vol 1 Nomor 3, Hal 107108.

Septiana, 2015. Lelang Jabatan Camat-Lurah Bisa Tingkatkan Kegairahan Birokrasi, detikNews, diakses Jumat, tgl 20 Februari 2015 Pukul 09.01 wita

Sunda, Cliff M. dan Johny Lumolos dan Sarah Sambiran, 2017. Kinerja Aparatur Sipil Negara dalam Pelayanan Publik Di Kelurahan Talikuran District Kawangkoan Utara, https://ejournal.unsrat.ac.id/index.php/jurnaleksekutif/article/view/15431

Undang-Undang Nomor 25 tahun 2009 Tentang Pelayanan Publik

Undang-Undang Aparatur Sipil Negara Nomor 5 Tahun 2014 Tentang Aparatur Sipil Negara

Utomo, Sad Dian. 2008. Penanganan Pengaduan Masyarakat Mengenai Pelayanan Publik. Jurnal IImu Administrasi dan Organisasi UI. Volume15, Nomor 3 SeptDes 2008. Hal:161-167. 